\title{
The Moral Obligation for Interlibrary Lending
}

Marianne Bamkin

Evidence Base: Birmingham City University 


\title{
The Moral Obligation for Interlibrary Lending
}

\begin{abstract}
A philosophical dilemma for librarians has arisen in this interconnected age, whether a library has a moral obligation to lend resources to another library. This discussion article examines a range of literature about interlibrary lending (interlending) and gives an account of librarians' perceptions of this quandary. The literature covers: the guidelines on interlending set out by library professional bodies; a historical view of interlending as well as more recent perceptions from librarians quoted in reports.

In order to explore the concept in more detail, taking a qualitative approach, a small questionnaire was circulated online to cross section of libraries in the Midlands region of the UK. The opinions of 11 self-selected participants were forthcoming, working in a range of academic, public and community led libraries. The data gathered this way was thematically categorised to identify the range of perceptions.

The views expressed in the questionnaire echoed those identified in the literature, forming three groups of moral attitude: no moral obligation, an obligation if it does not outweigh the costs, and a strong moral imperative to share resources. Participants identified the benefits of interlibrary lending and generally acknowledged that resource sharing was important. The importance of good customer service was highlighted as well as the imperative of supporting the ongoing operation of their library service.

Taking these perceptions into consideration, it was concluded that the question "is there a moral obligation for one library to lend to another" is not the right one to ask. The moral duty of a librarian is that access to information is maintained and resources are shared for the good of society as a whole.
\end{abstract}




\section{Key words}

Interlending, Interlibrary lending, morality, information, librarian,

\section{Introduction}

Two reports featuring interlibrary lending suggested that librarians face a philosophical dilemma in this age of digital information and e-resources. The "South Western Regional Library Service: Fundamental Review" examined the organisation's relevance to library collaboration and interlibrary lending (Bamkin \& Creaser, 2016) while "Interlending and resource-sharing in UK public libraries: a mixed methods study" (Wakeling, et al., 2016) reported the result of research commissioned by The Combined Regions (TCR) to understand an apparent decline in interlending.

Both studies unearthed a division between librarians of their perceived value of interlibrary lending but also suggested that some librarians considered that they had a moral duty to allow other libraries to borrow their books and resources because it benefits the end user. The difficulty arises that information is no longer merely recorded and contained as a physical object. This discussion paper examines the concept that a librarian feels duty bound to share resources with other libraries, considers the historical basis for this imperative and the reasons behind such thinking.

\section{Morals and Morality}

Moral judgements guide choice and decision making and are usually expressed with the terms "right, obligation, ought, duty, is to be done, should" (Snare, 1992). Morality is a code of what is right and what is wrong which can be understood as a set of rules that protect people from harm and cannot be changed by whim (Haidt, 2008). Moral behaviour is therefore the desire to perform acts that intrinsically benefit society.

\section{The problem}

The development of writing was a significant step in human history. It meant that thoughts and ideas could be recorded and passed down generations. Marks on stone, clay, wood, animal skin or paper assisted communication and the distribution of knowledge. Over the millennia artefacts, scrolls, books were gathered into libraries where librarians become gatekeepers of knowledge and intermediaries between individuals and the information contained in the artefacts.

For many decades, library procedure has facilitated any library to borrow or loan physically recorded information from another library - interlibrary lending (interlending). Systems were developed to share resources between public, academic, educational and institutional libraries through regional, national, international networks. (These systems are not the focus of this article and other authors have explained them in detail elsewhere). For more information and further reading about interlibrary lending and systems there is a list of articles and resources at the end of this document.

Interlibrary lending allows librarians to be proxies, borrowing resources from other libraries on behalf of their customers. These days, knowledge is not always held in a physical form. Electronic devices, e-resources, digital photography, capture knowledge through electronic impulses which be transferred as easily as pressing a computer key or touching a screen. In theory, borrowing a physical object to gain knowledge should no longer be necessary and the library or librarian does not need to be the intermediary between that information and the individual.

Except, not all information is on the internet; not all individuals find the internet easy to use; not all electronic information is free; not all electronic information belongs to the person who has the device or downloaded the e-book. Digitisation of archives takes time and effort to produce. All these things conspire to create barriers to libraries sharing their digital resources. One library borrowing the resources of another is no longer as straightforward as posting a book or photocopied journal article, sheet music or recorded media or even sending a pdf. 
Therefore the problem is, how far does the moral code of "doing the right thing" extend to librarians and library staff in their role of gatekeepers to knowledge? Is there really a moral obligation for libraries to share resources? And why do a group of library professionals take the view that it is their duty to lend resources to other libraries?

\section{Thoughts from professional bodies}

As part of their objectives, library and information professional organisations produce guidelines and state reasons for libraries to share resources. For example, the Document Delivery and Resource Sharing section of the International Federation of Library Associations (IFLA) clearly state in their guidelines that information professionals have a duty to share resources across all boundaries (IFLA, 2016). This is not simply a service to other libraries, but it is also a service to any end user, any person who needs or wants to know that information:

This section strongly believes that information is for the use of our users and facilitating the use of information across institutional and national boundaries is our duty as resource sharing professionals (IFLA, 2016).

IFLA draws its membership from many nations and naturally it promotes the global perspective of sharing resources between libraries in different countries.

This section supports the idea of the global library as a networked resource sharing organisation that enables access to resources through the collaboration of libraries worldwide (IFLA, 2016).

Consequently, the primary objective of the Document Delivery and Resource Sharing section is to promote and facilitate collaboration and sharing resources by national and international interlibrary lending as well as by electronic means.

Extend and improve document delivery and interlending both nationally and internationally through the use of new technology and increased co-operation among the librarians and document suppliers (IFLA, 2016)

The American Library Association (ALA) takes the perspective of the borrowing library. It believes that a library has an obligation to supply its users with information that they want but will have to draw on the resources of other libraries to be able to give good customer service. It considers that the interchange of resources brings strength and vigour to libraries.

In the interest of providing quality service libraries have an obligation to obtain material to meet the information needs of users when local resources do not meet their needs Interlibrary loan (ILL) is essential to the vitality of all libraries (ALA, 2016).

Therefore, for the good of society, resource sharing between libraries is a key element of their role.

... the sharing of materials between libraries is a core library service and believes it to be in the public interest to encourage such an exchange (ALA, 2016).

The Forum for Interlending and Information Delivery (FIL) is an organisation of the UK interlending community. It has a similar view point to IFLA, understanding that interlibrary lending is a global activity, which is expressed by one of their objectives.

To monitor and encourage international developments and co-operation in interlibrary loans and document supply (FiL, 2017).

FiL also consider that the quality of library services can be increased through modern practices as another objective states:

To promote and advance the science and practice of interlibrary loans and document supply to improve the overall standards of library services (FiL, 2017). 
It can therefore be concluded that Information and Library professional bodies firmly believe the following two concepts. Individuals have a right to access information and the role of a library and its staff is to act as a proxy to obtain that information on behalf of the individual. Collaborating and sharing resources with other libraries as part of a larger network not only fulfils their duty to facilitate information flows, but also enhances the individual library that requests the information by increasing its knowledge base and providing better customer service.

\section{Historical view}

As long ago as 1951 an editorial ${ }^{1}$ in Library World shows that social financial austerity is not a recent occurrence. The unnamed editor comments that:

"in this stringent time the greater part of the community depends upon the borrowed book. Inevitably this will increasingly be the case" (Editor, 1951).

The editor firmly states that librarians have a duty to enable the literacy of the population by supplying them with books.

"Our business as librarians should be to provide for the literate nation, indeed assist its making" (Editor, 1951)

The implication is that when a society is facing an economic downturn, libraries can provide readers with literature that would be beyond their limited budget. Fulfilling that duty can be aided by sourcing books from another library. The editorial explains that interlibrary lending is a transaction between two libraries. A library with more resources can help another with fewer resources. This can lead to a situation where some libraries lend more and are termed "net lenders" whilst other libraries borrow more and are termed "Net borrowers".

Runkle, (1992) considers that the desire to share information is a fundamental attribute of librarians.

"Librarians are by nature eager to co-operate and share collecting responsibilities"

This statement generalises the personalities of a group of individuals who may or may not be keen to share. White (2003) discusses the nature of librarians, whether they are "Bookmen" or "knowledge workers".

Bookmen are individuals that gather together collections and order in such a way that that it is easy to retrieve the information that they contain. On the other hand, knowledge workers are:

... Intermediaries who would steer us toward the correct and most up-to-date information, and away from the vague, the incorrect, and the obsolete (White, 2003).

Librarians who consider themselves knowledge workers, are specialists who have a role "saving the time of others" (White, 2003). The job of being a librarian is to facilitate access to information and literature for everyone. Therefore, working with the staff of other libraries to provide resources for all users is a natural extension of that role. Runkle (1992) suggests that librarians view interlibrary lending as a means to good customer service and facilitating the flow of information rather than a cost cutting exercise.

"Libraries have for many centuries looked to co-operation and resource sharing as a way of saving money. Academic Administrators see co-operation and resource sharing as a way of saving money. Librarians, on the other hand, see it as a way of expanding the information sources that can be made available to their constituencies, but not necessarily as a way of saving money. By co-operating librarians can provide information and services that they could not otherwise provide" (Runkle, 1992)

\footnotetext{
${ }^{1}$ Editorial from the Library World - April 1951
} 
Similarly, Hilyer (2002) reflects that there are so many possible resources that it is impossible for any library to hold everything that their customers may require. This means that interlibrary lending is essential for a good service.
"The perception of Interlibrary (Lending?) as a "Filler" measure is no longer valid, as libraries accept that their collections will not always be able to provide all the materials necessary to meet their patrons information needs." (Hilyer, 2002)

On the other hand, Simpson (1995) is of the opinion that interlibrary lending can come to the aid of a library with budgetary constraints by giving access to a wide range of resources, thereby allowing a library to concentrate on using their funds to spend on their core collections. Once again, this fulfils a librarian's role to facilitate their customers' needs and provide a good service.

\begin{abstract}
"The importance of resource sharing mechanisms ... is not so much that they will save us funds we can relocate to other purposes but that they will permit us to continue to have access to a large universe of materials we can no longer afford, spending our diminishing funds on the materials we need and use most. (Simpson, 1995)"
\end{abstract}

The imperative to share and the desire to run a cost effective service are not mutually exclusive concepts. Line and Cornish (1988) write that resource sharing is "morally desirable" and "economically imperative", but in order to keep a sense of perspective about resource sharing, buying an item is preferable to borrowing from another library if it is the cheaper option.

\title{
"Libraries should not borrow items from other libraries when it is more economic to buy them. An interlending system is a supplement to local provision, not an alternative" (Line, et al., 1988)
}

Line was director general of the British Library Lending Division at Boston Spa from 1974 to $1985^{2}$ and it was his vision of a centralised interlibrary lending system that led to the British Library Document Supply Service (BLDSS) which, to a certain degree can satisfy the urge for librarians to share resources while eliminating the unequal situation of net borrowing and net lending.

Writing in 1957, Uridge emphasises that according to the 1952 ACRL General Interlibrary Loan Code, there is no "right" that libraries must lend to each other - "Interlibrary Loan service is a courtesy and a privilege" (Uridge, 1957). For the service to work effectively requests should be well considered and restricted to only resources that cannot be accessed by "any other means". This is due to the costs arising from the service and to inhibit excess demands (Uridge, 1957). This attitude implies that Interlibrary lending may enable the flow of information, but only if it is a cheaper, or only option. This does not support the concept of the moral obligation for libraries to lend to each other. In this case, the transaction is seen as one between libraries alone and the end user of the information is not considered.

Of course there are costs involved with interlibrary lending such as postage or carrier charges, staff time and printing or photocopying. There is a debate about who should pay these costs. Myers (1991) outlines the moral arguments on one side for charges to users to recoup costs incurred by interlibrary lending for the economic survival of the library and on the other for the democratic right for anyone to have "Free and equal access to information", no matter who you are and how much money you have. Myers (1991) reminds us that libraries have a responsibility to their immediate community which should not be compromised by generosity to others.

$$
\begin{aligned}
& \text { "... the core group for whose benefit the library has been established should not be } \\
& \text { neglected in favour of providing altruistic services to others" (Myers, 1991). }
\end{aligned}
$$

White (2003) has a clear cut opinion of the process of interlibrary lending and its financial aspects. He considers that the only reason to acquire books or other information resources from another library for a "one-time use" should be purely "based on economic realities" not "on depending that someone else will find time to do you a

\footnotetext{
${ }^{2}$ http://www.bl.uk/aboutus/quickinfo/facts/history/line/
} 
favour" (White, 2003). He explains that although a library may have taken a financial decision not to purchase a certain resource it is a matter of good customer care, rather than moral duty, to acquire a requested resource as speedily as possible. Charges should be absorbed through the library's acquisition budget. The customer's priority is the information and has no view on whether it is borrowed from another library or purchased. White (2003) is clear that libraries no longer just lend books, and that the information can be in any form, which may well be supplied digitally.

Shaunghessy (1994) remarks that technological development has created barriers which prevent libraries being able to share resources with other libraries. Journals or books that are published electronically are not owned in the same way as print journals and books, which became the property of libraries and could be shared in their physical state. Licensing and copyright agreements mean that electronic publications are difficult to loan and borrow. Of course, it should be simpler to share an electronic resource and Shaunghessy (1994) points out that "Access is more important than ownership". His suggested solutions are having "Virtual Electronic Libraries" and digitising resources wherever possible.

Not all commentators on interlibrary lending are so positive about sharing. Kennedy (1995) for example, states that the moral dilemma is not whether librarians have an obligation to share, but that if libraries continue sharing resources it will bring "Vendors to their knees".

\section{Thoughts from library and information practitioners}

The initial intellectual spark for this line of academic questioning was kindled by the 2016 report by Wakeling et al, "Interlending and resource-sharing in UK public libraries: a mixed methods study". One of the report findings was that a certain number of public library staff considered that they had a "moral duty" to meet the needs of all library users, whereas others were more concerned about the operational cost of distributing their resources (Wakeling, et al., 2016). That ambivalence of attitude was echoed in the SWRLs report, the participants of which came from a wider range of libraries, including Higher Education (HE), Further Education (FE) and school librarians (Bamkin \& Creaser, 2016). In order to explore the concept a little further, Evidence Base asked a representative sample of library staff from a cross-section of library sectors and regions. Taking each of these studies in turn, we will examine the thoughts of people working in libraries who deal with interlibrary loans.

\section{The Wakeling report}

Wakeling et al (2016) were commissioned by the Combined Regions (TCR) to investigate the current decline in regional interlibrary lending and requests for documents through the British Library (BL). They conducted a survey and interviews with public library senior managers and interlibrary lending staff. Wakeling et al (2016) found that the rational for interlibrary lending given by library and information professionals was their "belief that knowledge should be unrestricted by ownership". Their survey asked about underlying reasons for providing interlibrary lending and the answers included "user demand", "responsibility to serve the community" and "Facilitating access to niche items".

"The most common reasons for offering an interlending service related to libraries duty to help users access the material they need. While it may be going too far to say that this was always perceived as a moral requirement, many interviewees felt that this represented a core part of the library offering. (Wakeling, et al., 2016)"

However, the sense of moral duty to serve their customers well and to disperse knowledge was conflicted by practical considerations such as the cost and staff time to do so. Some Library and Information professionals considered that the high financial and time investment for a minority of library users outweighs the moral argument while others believed that interlibrary lending can save costs.

"Interlending was therefore perceived as a mechanism for ensuring access for all to the widest possible range of material whilst also limiting expenditure" (Wakeling, et al., 2016). 
Interview results suggested that although interlibrary lending was declining from a national aspect, small sub regional schemes were working well, possibly due to shared values, and their use was beginning to increase. "We note that interlending is founded on the principles of cooperation" (Wakeling et al, 2016). It was mentioned that a survey of library users showed that access to information was their major priority. It was suggested that e-book suppliers such as Amazon, Google or Netflix now rival libraries and it was acknowledged that sharing electronic items is problematic due to unclear copyright and licensing legislation.

Three perspectives were shown for the moral imperative to offer interlibrary lending:

- A strong moral duty to meet needs of all library users

- The moral duty acknowledged, but tempered with practical concerns of cost

- No moral duty acknowledged with no justification to provide an expensive and time consuming service (Wakeling et al, 2016)

These attitudes illustrate that individuals who work in libraries have different outlooks, priorities and perception of their roles. The staff who believe that it is their moral duty consider that facilitating the flow of information is part of their job. Other staff put a greater emphasis on the keeping a library economically feasible.

\section{The SWRLS review}

SWRLS is a local regional organisation that has a long standing interlibrary lending scheme. It was originally formed in 1937 in order that public libraries in the South West of the UK could share their resources. At one time SWRLS had a union catalogue and an interlibrary lending bureau, employing its own staff. The organisation grew wider than a collaboration between public libraries alone and currently draws its membership from public, $\mathrm{HE}, \mathrm{FE}$, School and other libraries, consequently widening the possibility of cross sector interlibrary lending. Examining the attitudes towards interlibrary lending of cross sector library staff was therefore an important aspect of the SWRLs Fundamental Review (Bamkin and Creaser, 2016). The review was commissioned to examine the overall function of the service of which interlibrary lending is only part. The views that participants expressed were therefore about the value of interlibrary lending and not specifically about the moral imperative. However, their comments demonstrate their stance on the matter.

Some participants believed that being a member of SWRLS enabled them to save costs because interlibrary lending between members was less than the cost of borrowing through the British Library or other similar schemes. This echoes the point from the Wakeling report suggesting that regional ILL schemes are still being used. The importance of cost was emphasised by the participant who thought that interlending "is now a small but useful process as long as it is financially beneficial" (Bamkin \& Creaser, 2016).

Opinion was more divided in the case of a library's service to their users. Certain SWRLS members considered that their libraries' focus on e-books meant that the ability to borrow books in print did not reflect the needs of their users. The wide availability of electronic resources was given as a reason for not using interlibrary lending, as one participant commented "With more being done electronically, the need for interlending is getting less and less" (Bamkin \& Creaser, 2016). From this perspective, their libraries had the capability of supplying the information that their users required without the recourse to borrow from other libraries. These participants are making three assumptions: Interlending is for books only; their users will not want anything that the library cannot provide; and other libraries will not want to borrow the information that they hold.

However, interlending can apply to items other than books as noted by this participant in conversation with another:

"...it is more than books, its music sets, its play sets...

But it could be more...

Yes, it could be more, its alternative formats as well but what it isn't is articles as articles stand but it would be a fully bound magazine ..." (Bamkin \& Creaser, 2016)

Similarly, a user may want an obscure book from a special collection, for example, which is not digitised: 
"Yes, there will always be a need for some interlending of books that probably will never ever be digitised..." (Bamkin \& Creaser, 2016)

Participants also reported that they found difficulty in borrowing from certain libraries, public and academic, who are putting their own users first and are unwilling to share their resources. This suggests that a proportion of librarians only consider satisfying the information needs of their users only, not of library users in general. Such an outlook is not in sympathy with the moral obligation to meet the needs of all library users.

This apparent attitude can be explained by the pressures that libraries and librarians currently face. For example a rare book may be too fragile to lend:

"...but then a lot of those will not be loanable because the owners won't lend them because they're too valuable or too frail." (Bamkin \& Creaser, 2016)

University libraries have to justify the use of their resources in the context of fee paying students:

"We have had conversations about interlending and whether universities are net lenders and are they compensated effectively, when you've got your students paying, their expectation is different to perhaps 10 to 15 years ago, well longer." (Bamkin \& Creaser, 2016)

"Because some universities have stopped, I know XXX, we can't borrow anything from them, as a public library we'd want to but they've got their own agenda and are saying "well actually our students are paying more, we need to guarantee that we are looking after our students." (Bamkin \& Creaser, 2016)

On a more positive note, a larger number of participants thought that taking part in the interlibrary lending process was beneficial not only to the users of their libraries, but to people generally, and were critical of libraries that do not consider the wider population. For example, one participant stated:

"But to be honest, they need to be thinking about the wider benefits for their organisation and their community engagement and that kind of thing, so there are different focusses aren't there I think, at different levels of organisation." (Bamkin \& Creaser, 2016)

A participant who worked in a library with a unique collection expressed willingness to lend to other libraries:

"I did say that if anybody in the region wanted the kind of resources we've got, we'd still be very happy to lend them. So if anybody says "is there a database of libraries who are happy to lend things, or to allow people to come and use them" then we'd certainly want to be a part of that." (Bamkin \& Creaser, 2016)

Such a positive attitude demonstrated fulfilling the moral duty to facilitate information flows advocated by professional organisations:

"We like to be able to provide our materials to other local partners as part of our community engagement commitments." (Bamkin \& Creaser, 2016)

"So if we are going to continue to do interlibrary loans which, to be honest, for institutions like us we're net lenders but actually it's not a massive part of our role, it's not taking up too much time, so we are very happy to do that for the community and hopefully some of the other universities are." (Bamkin \& Creaser, 2016)

The positive attitude suggests an understanding that some libraries with less resources than others have more difficulty to supply their users with the information that they require. This is certainly the case of a participant who works in a further education college that is increasing the number of higher education courses that they deliver:

"The financial constraints are so massive and with universities most courses are franchised so we don't have access to university resources anymore and yet our HE is growing. One of the things that is 
particularly growing in FE is HNDs and HNCS - there's a massive resurgence of those... (Bamkin \& Creaser, 2016)"

Perhaps the most compelling statement of the value of interlibrary lending between a collaborative local organisations was from a school librarian:

"The ease of requesting books, and the variety of books available to help satisfy my student's requests sometimes they are very niche and our small library cannot meet this demand." And later, "As a school librarian who has to help with over 100 Extended Project Qualification research topics for A-Level students, SWRLS has been a fantastic help. I cannot afford to buy books for niche topics that will not be used again and so SWRLs helps me to provide high-quality information to my students without being wasteful." (Bamkin \& Creaser, 2016)

In this case, interlibrary lending is a cost effective way to provide resources for one-time use.

The value of interlibrary lending was expressed in terms of either financial cost or fulfilling a service to library users. The SWRLS participants had many opinions about the usefulness of interlibrary lending in this day and age, as did the participants to the Wakeling report. For some, there is less of a need for interlibrary lending as there is so much electronic resources available. Others emphasised that there will always be some unique and unusual resources that cannot be found digitally, although some items will be so rare that they will not be lent out. Some participants took an altruistic attitude and were happy to share their resources with smaller libraries who were pleased to be able to provide their customers with resources that they would not be able to acquire otherwise.

Other libraries were conscious of their responsibility to their own customers and were reluctant to loan their resources to the customers of other libraries. In general, the costs involved in interlibrary lending was a factor in their decisions, but the majority of the library staff considered that it was part of their role to provide their customers with the information they needed, and interlibrary lending was one method of doing so.

\section{The Evidence Base study}

In order to examine this concept in more detail, Evidence Base asked the following questions to a selection of library staff working in the Midlands region of the UK.

- Do you consider that there is a moral imperative for one library to lend resources to another?

- How does your library go about this?

- Who benefits from interlibrary lending?

- What costs occur from interlibrary lending?

- Do you consider that interlibrary lending can function in the current digital environment?

- How could the traditional process of physically transporting books from one library to another be updated in order to share resources?

Eleven participants from a variety of academic, public and community run libraries shared their views.

The participants were generally sympathetic with the concept of libraries lending resources between each other and their reactions fitted in with the three attitudes detected by Wakeling et al. Five participants considered that there is a moral imperative for one library to lend resources to another, giving comments such as:

Without doubt.

Yes, that is a good way of best utilisation of limited resources to provide a quality customer service.

Four participants thought that the term moral imperative was "too strong" but agreed that there is an understanding between libraries and "other information services" to co-operate and resources are lent in the spirit of "generosity" and "goodwill". One participant was more uncertain and considered that interlibrary lending is "indeed helpful" but that there may be exceptions for valuable items. Only one participant clearly stated that there was no moral obligation. 
The participants use local, national or international procedures or interlending schemes such as a shared catalogue, BL document delivery service or IFLA vouchers. They lend a varying selection of items. One stated that they only lend "physical items". Another is a net borrower but lends specialist items in the areas of Health and Music. One stated that they photocopy articles. Three stated their intention and willingness to fulfil requests promptly and whenever possible. The restrictions are when legally unable to lend, for example through copyright and licencing agreements. One participant stated that they lend digital items after checking "if we are legally allowed to provide copies of the item to other institutions".

All but one of the participants considered that, ultimately, both libraries and the general public benefit from interlibrary lending. Individual library members and members of the public "from all demographics" benefit from receiving "their information". The research community benefit by research staff and students having access to specialist resources and this leads to an overall benefit for society in general.

Arguably there is a similar albeit small benefit to society as a whole: society benefits from scientific research, and scientific research depends - to a very small extent - on interlibrary document supply.

Other benefits suggested by participants include:

- Authors gain more citations by their documents being read

- Library staff are employed in ILL roles

- Library budgets save on costs of purchasing and less duplication of resources

- Specialist collections are utilised

- ILL encourages partnership working

- ILL stimulates a positive perception of library services - they are "user friendly"

Negative aspects that were mentioned are that: large research libraries could become "net lenders", they lend more than they borrow; "commercial colleagues" may "find it unpopular". One participant was of the opinion that only a small number of library members benefit from interlibrary lending.

The costs incurred by interlibrary lending that were listed by participants are those of transporting and posting items, stationary and packaging, and administrative costs such as BL fees or voucher schemes. However these costs are subsided in some libraries by charging the public although the fees do not recoup all the expenditure. It was generally felt that there will be an ongoing need for physical items and that current forms of transportation and postage by Royal Mail are satisfactory. The situation surrounding copyright and licencing of e-books was mentioned as a barrier to digital lending, which would be an efficient method for e-books and other e-resources.

\section{E-resource licensing agreements should always allow for interlibrary cooperation in line with what is permitted by the CDPA 1988 (as amended). The interlibrary supply of 'born- digital' journal articles is already happening: it seems to me that interlibrary sharing of e- books should be made possible.}

Other suggestions were made such as delivering to Amazon style lockers or a shared logistics network.

\section{Conclusion}

The question of whether libraries and librarians have a moral duty to lend resources to other libraries is perhaps not the right question to ask. The themes identified in this document focus on the perceptions of individual library workers and their concepts of: morality; the role of a librarian; and service to customers and their own organisation.

Librarians and library staff do not all belong to a specific personality type and therefore have as wide a range of views as any member of the population. They are all trained in library and information work to a variety of levels and have professional organisations that compile guidelines on how their job should be performed. Understandably, the place where they work and the priorities of their role have a bearing on their attitude to 
interlibrary lending. Is the role of the librarian to keep information safe or to spread it around for the good of society?

In a situation where a library has budgetary constraints and in a climate where the justification of spending money is a major priority, the financial aspect of interlibrary lending becomes important, either to acquire resources, or to be used by their own customers. The morality of the situation is to ensure that their library service continues into the future, providing resources and information to its members.

By their training library staff are encouraged to believe that they have a role to disseminate information, to facilitate information flows, helping individuals to find information or literature easily. When the working priority of an individual is to get the right information to the right person their perception of fulfilling their role means that they will find the resource by any reasonable means, which could be digitally, could be purchased, or could be through borrowing that resource from somewhere else. The morality of that situation is that access to information is maintained, resources are shared for the good of society as a whole.

The answer is not that libraries have a moral obligation to lend items to other libraries, but that a moral librarian who wants to fulfil their role will use interlibrary lending as one tool to provide excellent customer service and to ensure that anyone, not matter who they are, can acquire the information that they need at the time that they need it.

\section{References}

ALA (2016) Interlibrary Loan Code for the United States.

Available at: http://www.ala.org/rusa/sites/ala.org.rusa/files/content/ILL\%20Code\%20with\%20Supplement 1120-17 updated-link.pdf

(Accessed 15 August 2017).

Bamkin M R and Creaser C (2016) South West Regional Library Service: Fundamental Review. Report, Loughborough Universtiy, UK, July.

Editor (1951) Editorial. The Library World, LIII(610): 229.

FiL (2017) Forum for interlending and information delivery. Available at: http://www.forumforinterlending.org.uk/best-practice-guidelines (Accessed 7 July 2017).

Haidt J (2008) Morality. Perspectives on Pyschological Science. 3(1): 65-72.

Hilyer L A (2002) Interlibrary Loan and Documentation Delivery in the Larger Academic Library. New York and London: Haworth Press.

IFLA (2016) IFLA Document Delivery and Resource Sharing Group. Available at: https://www.ifla.org/docdel (Accessed 19 July 2017).

Kennedy K (1995) Access Blues: the song we are all singing. Journal of Library Administration, 20(1): 49-58.

Line M and Cornish P G (1988). Line on Interlending: selected papers on interlending and document supply. Boston Spa: British Library.

Myers G (1991) Robin Hood in Interlending: Charging the information rich to help the information poor. Interlending and document supply, 9(1): 3-6.

Runkle M (1992) The Changing Economics of Research Libraries. In: J. B. Sutton and C. Davis (eds) Networks, Open Access and Virtual Libraries: Implications for the Research Library. Urbana-Champaign: Universtiy of Illinois, pp. 115-6.

Shaunghessy T (1994) Resource sharing: the end of innocence. In: S. H. Lee (ed) Access, Ownership and Resource Sharing. New York and London: Haworth Press, pp. 5-6. 
Simpson D B (1995) Resource sharing = access + ownership: Balancing the equation in an unbalanced world. Journal of Library Adminstration, 20:101-102.

Snare F (1992) The Nature of Moral Thinking. London and New York: Routledge.

Uridge M (1957) Interlibrary Lending and Similar Extentsion Services. Library Trends: Current trends in circulation services, 6(1): 68-88.

Wakeling S, Rutter S and Birdi B P S (2016). Interlending and resource sharing in the UK public libraries: a mixed methods study. Journal of Librarianship and Information Science. Epub ahead of print. 30 March 2016 http://dx.doi.org/10.1177/0961000616637670

White H S (2003) The Successful Future of the Librarian: Bookman or Knowledge Worker? Australian Academic and Research Libraries. 34(1): 1-13.

\section{Further Reading}

Baker D (1997) Document delivery: access versus holdings. Librarian Career Development 5 (3).

Beaubien A (2007) ARL White Paper on Interlibrary Loan. Association of Research Libraries.

Birch K, Goldner M and Parson K (2013) Seven degrees of interlibrary lending. Interlending and Document Supply 41(1): 12-17.

Bradford J and Brine JJ (2006) Interlending and Document Supply in Britain Today. Oxford: Chandos.

Klugkist A (1995) Open Library Networking and Interlibrary Cooperation. In: Information Superhighway: The Role of Librarians, Information Scientists and Intermediaries. Essen: Essen University Library: 276-286.

Litsey R and Ketner K (2013) Oh the Possibilities: ebook lending and interlibrary loan. Interlending and Document Supply 41(4): 120-121.

Melinat C (1954) Interlibrary Lending. Library Trends. Available at: 4814879.pdf (accessed 3 September 2020).

Muller H (2012) Legal Aspects of e-books and interlibrary loan. In: Interlending and Document Supply, San Juan, 2012, pp. 150-155. Emerald.

Munson K and Thompson H (2019) International Interlibrary Loan in a Changing Environment: Results from the 2019 RUSA STARS International ILL Survey. In: IFLA, Prague, 2019. IFLA.

Oberlander (2006) Emergent Resource Sharing and ILL. Available at: emergent resource sharing and ILL.pdf.

Wakeling S, Rutter S, Birdi B, et al. (2016) Interlending and resource sharing in UK public libraries: a mixed method study. Journal of Librarianship and Information Science March.

Walton J (2008) The changing use of electronic document delivery in the interlibrary loan service: a survey. Interlending and Document Supply 36(1): 43-56.

WANYAMA P (1993) Interlibrary lending services: a comparative study of Britain and Kenya. Master's thesis. Loughborough University, UK

Wright C (1997) From barter to business - a moral history of charging for interlibrary loans. Interlending and Document Supply 25(2): 51-56. 